\title{
Ongoing Survey Research on Post-9/11 Veterans
}

\author{
Teryn Mattox and Michael Pollard
}

\section{Key findings}

- There are 11 nationally representative and repeated surveys of post-9/11 U.S. veterans.

- All 11 surveys were funded through federal agencies.

- Seven surveys were repeated cross-sectional surveys, one was a longitudinal survey, and three were overlapping panel surveys.

- Four surveys were focused specifically on sampling veteran populations, while the other seven surveys sampled the civilian population more broadly. Three of the four veteran-focused surveys had veteran health outcomes as their primary research questions, while the fourth focused on veteran service utilization.

- Many of these surveys can be used to examine issues related to the veteran transition to civilian life at one point in time or over multiple points. However, these surveys are not able to examine how individual veterans fare over time in their transitions to civilian life.

- There is no longitudinal or overlapping panel survey that specifically examines issues uniquely relevant to the transition to civilian life for post-9/11 veterans and related outcomes.
$\mathrm{F}$ ederal agencies, researchers, and veterans' advocacy groups have issued imperatives highlighting important gaps in our knowledge of the trajectory of reintegration and related problems faced by post-9/11 veterans. ${ }^{1}$ There are a number of ongoing surveys that can be used to address the needs of post-9/11 veterans, but no comparative information exists that assesses the strengths and weaknesses of these efforts. To that end, this report documents the results of a review of the survey research landscape examining post-9/11 veterans. We limited our search to repeated surveys because surveys conducted in an ongoing way can provide rich information about the trajectory of veterans' well-being over time.

\section{METHODOLOGY}

This report is based on an environmental scan (conducted between January 1, 2007, and January 1, 2014) of repeated surveys of post-9/11 U.S. military veterans. The results include repeated cross-sectional surveys and longitudinal surveys following the same individuals or households over time.

We included surveys with sample sizes of more than 1,000 post-9/11 veterans per administration and excluded hundreds of studies conducted within specific veteran populations for use in clinical trials. We only included surveys intended to be nationally representative of the veteran population or nationally representative of a specific subpopulation of veterans (e.g., women veterans or veterans with posttraumatic stress disorder [PTSD]). To that end, we excluded surveys with a specific region of focus (e.g., by state or county), as well as member surveys conducted by veterans' service organizations, and we excluded surveys that used nonprobabilistic selection procedures, such as convenience or snowball sampling. We also included those nationally representative surveys of the general U.S. population with an estimated sample size of at least 1,000 post-9/11 veterans per administration with data on veteran status even if the surveys did not explicitly report veteran 


\section{These surveys are able to examine group-level changes over time and can therefore be useful in analyzing population trends.}

outcomes. Note that some of these national surveys did not ask about dates of service, so post-9/11 veterans were not possible to directly identify in some cases.

To execute the scan, we conducted targeted searches of Google, Google Scholar, and PubMed to locate highly cited publications and technical reports, as well as grey literature produced by veteran-serving and other organizations. We furthermore identified surveys using reference mining (i.e., locating reports that cited key reports or were cited by those reports).

Identified surveys were categorized according to sampling frame, design and frequency of administration, population of focus, method of administration, funding source, and overarching purpose.

The survey sampling frame is the source from which the survey sample is drawn. Understanding the sampling frame can provide important information related to the broad representativeness of a survey. Veterans can be difficult to locate for survey research, and in fact there is no complete administrative list that houses up-to-date contact information for all veterans. ${ }^{2}$ Despite this, researchers often employ sampling frames based on Department of Veterans Affairs (VA) or Department of Defense (DoD) administrative lists to identify veterans. In one common list-based sampling frame, veteran survey participants are identified via their connections to programs and services, most commonly through veterans' engagement with VA health centers. While this is an appropriate sampling frame in certain situations, this type of sampling has been found to be particularly inadequate when the goal is to obtain comprehensive rep- resentativeness of the veteran population, because most veterans obtain their health care outside the VA health system, and VA users are distinctly different from non-VA users. ${ }^{3}$ Alternatively, address-based sampling (ABS) frames are those that sample from the entire universe of residential addresses. These frames are considered the gold standard for obtaining broad representativeness of the civilian noninstitutionalized population but can be low-yield and thus costly for researchers or institutions interested only in surveying a small subset of the entire population, such as veterans. ${ }^{4}$

Survey designs included repeated cross-sectional surveys, longitudinal surveys, and overlapping panel surveys. Repeated cross-sectional surveys ask similar information of a different sample of individuals or households for each survey administration. These surveys are able to examine group-level changes over time and can therefore be useful in analyzing population trends. These surveys cannot be used to look at individual-level changes over time, apart from retrospective reports within surveys. Longitudinal surveys, on the other hand, involve following the same individuals or households prospectively over time and are useful for following individual-level trends. ${ }^{5}$ For our purposes, longitudinal survey refers to the typical longitudinal survey following a single panel of individuals over the medium or long term. One subset of longitudinal surveys, called overlapping panel surveys, follow multiple groups of individuals over a fixed period, with each group's survey timeline overlapping. ${ }^{6}$ We categorized these separately because they represent something of a hybrid approach between cross-sectional and longitudinal survey designs.

\section{RESULTS}

Our search identified 11 surveys, which are described in detail in Table 1. Surveys of exclusively veteran samples are in bold; longitudinal and overlapping panel surveys have been highlighted in gray.

All identified surveys were funded through federal agencies. Seven surveys were repeated cross-sectional surveys, one was a longitudinal survey, and three were overlapping panel surveys. Eight of the identified surveys utilized ABS frames, such as the U.S. Postal Service address file or the U.S. Census 
Table 1. Identified Surveys

\begin{tabular}{|c|c|c|c|c|c|c|}
\hline Survey & Population & $\begin{array}{l}\text { Sample } \\
\text { Frame }\end{array}$ & $\begin{array}{l}\text { Data- } \\
\text { Collection } \\
\text { Method }\end{array}$ & $\begin{array}{l}\text { Design and } \\
\text { Frequency }\end{array}$ & Funder & Purpose \\
\hline $\begin{array}{l}\text { American } \\
\text { Community } \\
\text { Survey } \\
\text { (ACS)a }\end{array}$ & U.S. households & $\begin{array}{l}\text { U.S. Census } \\
\text { Bureau's } \\
\text { Master } \\
\text { Address File }\end{array}$ & $\begin{array}{l}\text { Online, mail, } \\
\text { telephone, and } \\
\text { personal-visit } \\
\text { interviews }\end{array}$ & $\begin{array}{l}\text { Repeated } \\
\text { cross-sectional; } \\
\text { conducted } \\
\text { monthly to } \\
\text { produce annual } \\
\text { estimates }\end{array}$ & $\begin{array}{l}\text { U.S. Census } \\
\text { Bureau }\end{array}$ & $\begin{array}{l}\text { The ACS provides } \\
\text { estimates of selected } \\
\text { social, economic, and } \\
\text { housing characteristics } \\
\text { of the U.S. population }\end{array}$ \\
\hline $\begin{array}{l}\text { Current } \\
\text { Population } \\
\text { Survey (CPS) }\end{array}$ & $\begin{array}{l}\text { U.S. civilian non- } \\
\text { institutionalized } \\
\text { population ages } 16 \\
\text { and older }\end{array}$ & U.S. Census & $\begin{array}{l}\text { Telephone and } \\
\text { personal-visit } \\
\text { interviews }\end{array}$ & $\begin{array}{l}\text { Repeated } \\
\text { cross-sectional; } \\
\text { conducted } \\
\text { monthly }\end{array}$ & $\begin{array}{l}\text { U.S. Census } \\
\text { Bureau }\end{array}$ & $\begin{array}{l}\text { The CPS produces } \\
\text { demographic and } \\
\text { socioeconomic } \\
\text { information for the } \\
\text { U.S. population }\end{array}$ \\
\hline $\begin{array}{l}\text { Medical } \\
\text { Expenditure } \\
\text { Panel Survey } \\
\text { (MEPS) } \\
\text { Household } \\
\text { Component }\end{array}$ & $\begin{array}{l}\text { U.S. civilian non- } \\
\text { institutionalized } \\
\text { population ages } 18 \\
\text { and older }\end{array}$ & $\begin{array}{l}\text { Respondents } \\
\text { to the } \\
\text { National } \\
\text { Health } \\
\text { Interview } \\
\text { Survey }\end{array}$ & $\begin{array}{l}\text { Mail, } \\
\text { telephone, and } \\
\text { personal-visit } \\
\text { interviews }\end{array}$ & $\begin{array}{l}\text { Overlapping } \\
\text { panel; a new } \\
\text { panel is selected } \\
\text { each year } \\
\text { and data for } \\
\text { each panel } \\
\text { are collected } \\
\text { in } 5 \text { rounds of } \\
\text { interviewing over } \\
\text { two and a half } \\
\text { years }\end{array}$ & $\begin{array}{l}\text { The Agency } \\
\text { for Healthcare } \\
\text { Research and } \\
\text { Quality (AHRQ) }\end{array}$ & $\begin{array}{l}\text { The MEPS Household } \\
\text { Component collects } \\
\text { data on health } \\
\text { insurance costs, as } \\
\text { well as utilization and } \\
\text { costs of specific health } \\
\text { services for the U.S. } \\
\text { population }\end{array}$ \\
\hline $\begin{array}{l}\text { Millennium } \\
\text { Cohort } \\
\text { Study } \\
\text { (MCS)d }\end{array}$ & $\begin{array}{l}\text { Active-duty, } \\
\text { reserve, and } \\
\text { National Guard } \\
\text { members from } \\
\text { all services }\end{array}$ & $\begin{array}{l}\text { Department } \\
\text { of Defense } \\
\text { Manpower } \\
\text { Data Center } \\
\text { (DMDC) }\end{array}$ & Mail, online & $\begin{array}{l}\text { Overlapping } \\
\text { panel; data } \\
\text { for each of } \\
\text { four panels } \\
\text { are collected } \\
\text { every } 3 \text { years }\end{array}$ & $\begin{array}{l}\text { U.S. } \\
\text { Department of } \\
\text { Defense }\end{array}$ & $\begin{array}{l}\text { The MCS } \\
\text { examines the } \\
\text { impact of military } \\
\text { exposures on } \\
\text { long-term veteran } \\
\text { health outcomes }\end{array}$ \\
\hline $\begin{array}{l}\text { National } \\
\text { Health } \\
\text { Interview } \\
\text { Survey } \\
\text { (NHIS)e }^{\text {NHIS }}\end{array}$ & $\begin{array}{l}\text { U.S. civilian } \\
\text { non- } \\
\text { institutionalized } \\
\text { population ages } \\
18 \text { and older }\end{array}$ & U.S. Census & $\begin{array}{l}\text { Personal- } \\
\text { visit } \\
\text { interviews }\end{array}$ & $\begin{array}{l}\text { Repeated } \\
\text { cross- } \\
\text { sectional; } \\
\text { conducted } \\
\text { continuously } \\
\text { to produce } \\
\text { annual data } \\
\text { files }\end{array}$ & $\begin{array}{l}\text { U.S. } \\
\text { Department } \\
\text { of Health } \\
\text { and Human } \\
\text { Services, } \\
\text { Centers for } \\
\text { Disease Control } \\
\text { and Prevention, } \\
\text { and National } \\
\text { Center for } \\
\text { Health Statistics }\end{array}$ & $\begin{array}{l}\text { The NHIS collects } \\
\text { a broad range } \\
\text { of information } \\
\text { on the health } \\
\text { of the U.S. non- } \\
\text { institutionalized } \\
\text { civilian population }\end{array}$ \\
\hline
\end{tabular}




\begin{tabular}{|c|c|c|c|c|c|c|}
\hline Survey & Population & $\begin{array}{l}\text { Sample } \\
\text { Frame }\end{array}$ & $\begin{array}{l}\text { Data- } \\
\text { Collection } \\
\text { Method }\end{array}$ & $\begin{array}{l}\text { Design and } \\
\text { Frequency }\end{array}$ & Funder & Purpose \\
\hline $\begin{array}{l}\text { National } \\
\text { Survey of } \\
\text { Veterans } \\
\text { (NSV) }^{f}\end{array}$ & $\begin{array}{l}\text { U.S. non- } \\
\text { institutionalized } \\
\text { veteran population }\end{array}$ & $\begin{array}{l}\text { U.S. Postal } \\
\text { Service list of } \\
\text { all residential } \\
\text { addresses } \\
\text { (for veteran } \\
\text { portion) }\end{array}$ & Mail, online & $\begin{array}{l}\text { Repeated } \\
\text { cross-sectional; } \\
\text { conducted in } \\
1979,2001 \text {, and } \\
2010\end{array}$ & $\begin{array}{l}\text { U.S. Department of } \\
\text { Veterans Affairs }\end{array}$ & $\begin{array}{l}\text { The NSV collects } \\
\text { information for } \\
\text { the Department of } \\
\text { Veterans Affairs to } \\
\text { use in planning and } \\
\text { allocating resources } \\
\text { for programs and } \\
\text { services for veterans }\end{array}$ \\
\hline $\begin{array}{l}\text { National } \\
\text { Survey on } \\
\text { Drug Use } \\
\text { and Health } \\
\text { (NSDUH)g }\end{array}$ & $\begin{array}{l}\text { U.S. civilian non- } \\
\text { institutionalized } \\
\text { population ages } 12 \\
\text { and older }\end{array}$ & $\begin{array}{l}\text { Individuals } \\
\text { within } \\
\text { observed } \\
\text { dwelling units } \\
\text { within U.S. } \\
\text { Census tracts }\end{array}$ & $\begin{array}{l}\text { Personal-visit } \\
\text { interviews }\end{array}$ & $\begin{array}{l}\text { Repeated } \\
\text { cross-sectional, } \\
\text { conducted } \\
\text { annually }\end{array}$ & $\begin{array}{l}\text { The Substance } \\
\text { Abuse and Mental } \\
\text { Health Services } \\
\text { Administration, } \\
\text { an agency in the } \\
\text { U.S. Department of } \\
\text { Health and Human } \\
\text { Services }\end{array}$ & $\begin{array}{l}\text { The NSDUH examines } \\
\text { the use of tobacco } \\
\text { products, alcohol, and } \\
\text { illicit drugs (including } \\
\text { nonmedical use of } \\
\text { prescription drugs), as } \\
\text { well as mental health } \\
\text { in the United States }\end{array}$ \\
\hline $\begin{array}{l}\text { Project } \\
\text { VALOR }^{h}\end{array}$ & $\begin{array}{l}\text { U.S. Army or } \\
\text { Marine Corps } \\
\text { veterans who } \\
\text { were deployed } \\
\text { to combat in } \\
\text { support of } \\
\text { Operation } \\
\text { Enduring } \\
\text { Freedom or } \\
\text { Operation } \\
\text { Iraqi Freedom, } \\
\text { with PTSD and } \\
\text { without PTSD } \\
\text { (comparison } \\
\text { group) }\end{array}$ & $\begin{array}{l}\text { Department } \\
\text { of Veterans } \\
\text { Affairs } \\
\text { health care } \\
\text { system } \\
\text { inpatient or } \\
\text { outpatient } \\
\text { databases }\end{array}$ & $\begin{array}{l}\text { Online, } \\
\text { telephone }\end{array}$ & $\begin{array}{l}\text { Longitudinal; } \\
\text { conducted } \\
\text { annually }\end{array}$ & $\begin{array}{l}\text { U.S. } \\
\text { Department of } \\
\text { Defense }\end{array}$ & $\begin{array}{l}\text { Project VALOR } \\
\text { examines patterns } \\
\text { and predictive } \\
\text { measures for } \\
\text { development or } \\
\text { remission of PTSD }\end{array}$ \\
\hline $\begin{array}{l}\text { Survey of } \\
\text { Business } \\
\text { Owners and } \\
\text { Self-Employed } \\
\text { Persons } \\
\text { (SBO) }\end{array}$ & $\begin{array}{l}\text { U.S. business } \\
\text { owners }\end{array}$ & $\begin{array}{l}\text { IRS databases } \\
\text { on all } \\
\text { companies } \\
\text { reporting } \\
\text { any business } \\
\text { activity }\end{array}$ & Online & $\begin{array}{l}\text { Repeated } \\
\text { cross-sectional; } \\
\text { conducted every } \\
5 \text { years }\end{array}$ & $\begin{array}{l}\text { U.S. Census } \\
\text { Bureau }\end{array}$ & $\begin{array}{l}\text { The SBO collects } \\
\text { information on } \\
\text { economic and } \\
\text { demographic } \\
\text { characteristics of } \\
\text { businesses and } \\
\text { business owners }\end{array}$ \\
\hline
\end{tabular}




\begin{tabular}{|c|c|c|c|c|c|c|}
\hline Survey & Population & $\begin{array}{l}\text { Sample } \\
\text { Frame }\end{array}$ & $\begin{array}{l}\text { Data- } \\
\text { Collection } \\
\text { Method }\end{array}$ & $\begin{array}{l}\text { Design and } \\
\text { Frequency }\end{array}$ & Funder & Purpose \\
\hline $\begin{array}{l}\text { Survey of } \\
\text { Income and } \\
\text { Program } \\
\text { Participation } \\
\text { (SIPP)i }\end{array}$ & $\begin{array}{l}\text { U.S. civilian non- } \\
\text { institutionalized } \\
\text { population ages } 15 \\
\text { and older }\end{array}$ & $\begin{array}{l}\text { U.S. Census } \\
\text { Bureau's } \\
\text { Master } \\
\text { Address File }\end{array}$ & $\begin{array}{l}\text { Personal-visit } \\
\text { interviews }\end{array}$ & $\begin{array}{l}\text { Overlapping } \\
\text { panel; a new } \\
\text { panel is selected } \\
\text { every } 3-4 \text { years, } \\
\text { and data for } \\
\text { each panel are } \\
\text { collected every } \\
4 \text { months for up } \\
\text { to } 5 \text { years }\end{array}$ & $\begin{array}{l}\text { U.S. Census } \\
\text { Bureau }\end{array}$ & $\begin{array}{l}\text { SIPP collects data } \\
\text { on socioeconomic } \\
\text { status, well-being, and } \\
\text { program participation }\end{array}$ \\
\hline $\begin{array}{l}\text { Survey of } \\
\text { Veteran } \\
\text { Enrollees' } \\
\text { Health and } \\
\text { Reliance } \\
\text { upon VA } \\
\text { (Survey of }^{\text {Enrollees) }}\end{array}$ & $\begin{array}{l}\text { Veterans } \\
\text { enrolled in the } \\
\text { Veterans Health } \\
\text { Administration } \\
\text { (VHA) }\end{array}$ & $\begin{array}{l}\text { VHA } \\
\text { Enrollment } \\
\text { File }\end{array}$ & Telephone & $\begin{array}{l}\text { Repeated } \\
\text { cross- } \\
\text { sectional; } \\
\text { conducted } \\
\text { annually }\end{array}$ & $\begin{array}{l}\text { U.S. } \\
\text { Department } \\
\text { of Veterans } \\
\text { Affairs }\end{array}$ & $\begin{array}{l}\text { The Survey } \\
\text { of Enrollees } \\
\text { provides essential } \\
\text { information on } \\
\text { veteran utilization } \\
\text { of health services } \\
\text { to the U.S. } \\
\text { Department of } \\
\text { Veterans Affairs }\end{array}$ \\
\hline
\end{tabular}

NOTE: Surveys including exclusively veteran samples are in bold; longitudinal and overlapping panel surveys are in gray.

a C. H. Alexander, "Still Rolling: Leslie Kish's 'Rolling Samples' and the American Community Survey," Survey Methodology, Vol. 28, No. 1, 2002, pp. 35-42; U.S. Census Bureau, "Sample Design and Selection," in American Community Survey Design and Methodology (January 2014), version 2.0, Washington, D.C., 2014.

b U.S. Census Bureau, Technical Paper 66: Design and Methodology, Current Population Survey, Washington, D.C., 2006.

c J. W. Cohen, A. C. Monheit, K. M. Beauregard, S. B. Cohen, D. C. Lefkowitz, D. E. Potter, J. P. Sommers, A. K. Taylor, R. H. Arnett III, "The Medical Expenditure Panel Survey: A National Health Information Resource," Inquiry, Vol. 33, No. 7, 1996-1997, pp. 373-389; S. B. Cohen, "Design Strategies and Innovations in the Medical Expenditure Panel Survey," Medical Care, Vol. 41, No. 7, 2003, pp. III-5-III-12.

d M. A. Ryan, T. C. Smith, B. Smith, P. Amoroso, E. J. Boyko, G. C. Gray, G. D. Gackstetter, J. R. Riddle, T. S. Wells, G. Gumbs, T. E. Corbeil, and T. I.

Hooper, "Millennium Cohort: Enrollment Begins a 21-Year Contribution to Understanding the Impact of Military Service," Journal of Clinical Epidemiology,

Vol. 60, No. 2, 2007, pp. 181-191

e Centers for Disease Control and Prevention, "About the National Health Interview Survey," October 8, 2015 las of August 1, 2016

http://www.cdc.gov/nchs/nhis/about_nhis.htm).

f Westat, National Survey of Veterans, Active Duty Service Members, Demobilized National Guard and Reserve Members, Family Members, and Surviving Spouses, Washington, D.C.: U.S. Department of Veterans Affairs, 2010.

g Substance Abuse and Mental Health Services Administration, Behavioral Health Trends in the United States: Results from the 2014 National Survey on Drug Use and Health, Washington, D.C.: U.S. Department of Health and Human Services, 2015

h R. C. Rosen, Brian P. Marx, Nancy N. Maserejian, Darren W. Holowka, Margaret A. Gates, Lynn A. Sleeper, Jennifer J. Vasterling, Han K. Kang, and Terence M. Keane, "Project VALOR: Design and Methods of a Longitudinal Registry of Post-Traumatic Stress Disorder (PTSD) in Combat-Exposed Veterans in the Afghanistan and Iraqi Military Theaters of Operations," International Journal of Methods in Psychiatric Research, Vol. 21, No. 1, 2012, pp. 5-16.

i U.S. Census Bureau, "Survey of Business Owners and Self-Employed Persons (SBO): Methodology," February 9, 2016 (as of May 11, 2016 :

https://www.census.gov/programs-surveys/sbo/technical-documentation/methodology.htmll.

i U.S. Census Bureau, "Survey of Income and Program Participation: Methodology," January 18, 2016 las of May 11, 2016:

http://www.census.gov/programs-surveys/sipp/methodology.htmll.

k U.S. Department of Veterans Affairs, 2011 Survey of Veteran Enrollees' Health and Reliance upon VA: With Selected Comparison to the 1999-2010 Surveys,

Washington, D.C., March 2012. 


\section{There is no longitudinal or overlapping panel survey that specifically examines issues uniquely relevant to the transition to civilian life for post-9/11 veterans and related} outcomes.

Master Address File. Note that no identified surveys followed a random-digit-dial approach with lists of telephone numbers for identifying a sampling frame. The other three surveys used VA or DoD administrative lists to identify a sample. All three surveys utilizing list-based sampling were focused on issues related to health, and three of the eight ABS surveys were focused specifically on health.

Four surveys were focused specifically on sampling veteran populations (bolded in Table 1), while the other seven surveys sampled the civilian population more broadly. Three of the four veteran-focused surveys had veteran health outcomes as their primary research questions, while the fourth focused on veteran service utilization.

\section{DISCUSSION}

This review provides a comprehensive look at nationally representative and repeated surveys of post-9/11 U.S. military veterans. We identified 11 surveys as having sufficient sample sizes (or estimated sample sizes) of post-9/11 veterans and robust sampling procedures. Most of the identified surveys were very large national surveys of the civilian population, with estimated sample sizes of greater than 1,000 post-9/11 veterans.

There is no longitudinal or overlapping panel survey that specifically examines issues uniquely relevant to the transition to civilian life for post-9/11 veterans and related outcomes. The SIPP is the only longitudinal or overlapping panel survey that includes a sufficient estimated sample of post-9/11 veterans and does not focus exclusively on health-related issues. The SIPP is a survey of the general population conducted by the U.S. Census Bureau and uses the U.S. Census's Master Address File. The survey contains questions related to socioeconomic status, including well-being, labor force participation, income, assets, education, and program utilization. The SIPP includes veteranspecific questions related to VA benefits and service utilization, including GI Bill utilization. The SIPP is not designed to follow veterans through the trajectory of their transitions to civilian life, as the duration of each SIPP panel ranges from two and a half years to four years.

There is a broader assortment of repeated cross-sectional surveys with a sufficient estimated sample of post-9/11 veterans. The majority of these surveys use U.S. Census data to conduct ABS, and they cover a range of topics. These surveys are most frequently concerned with topics related to health and health care utilization but also address employment, socioeconomic status, benefit utilization, and housing. Many of these surveys, particularly those aimed specifically at veteran populations, can be used to examine issues related to the veteran transition to civilian life at one point in time or over multiple points. Because of their cross-sectional nature, however, these surveys are not able to examine how individual veterans fare over time in their transition to civilian life.

Here we have identified the resources that are currently available to examine trends in issues related to post-9/11 veterans. This information should be useful to researchers and policymakers interested in the breadth, quality, and representativeness of longitudinal and ongoing cross-sectional research on veterans. 


\section{Notes}

${ }^{1}$ U.S. Department of Veterans Affairs, Veterans Policy Research Agenda, Washington, D.C.: Office of Policy and Planning, 2016; U.S. Interagency Council on Homelessness, National Research Agenda: Priorities for Advancing our Understanding of Homelessness, Washington, D.C., 2012; E. M. Yano, Lori A. Bastian, Susan M. Frayne, Alexandra L. Howell, Linda R. Lipson, Geraldine McGlynn, Paula P. Schnurr, Margaret R. Seaver, Ann M. Spungen, and Stephan D. Fihn, “Toward a VA Women's Health Research Agenda: Setting Evidence-Based Priorities to Improve the Health and Health Care of Women Veterans," Journal of General Internal Medicine, Vol. 21, Supp. 3, 2006, pp. S93-S101.

${ }^{2}$ D. L. Washington, S. Sun, and M. Canning, "Creating a Sampling Frame for Population-Based Veteran Research: Representativeness and Overlap of VA and Department of Defense Databases," Journal of Rehabilitation Research and Development, Vol. 47, No. 8, 2010, pp. 763-771.
${ }^{3}$ J. A. Long, D. Polsky, and J. P. Metlay, "Changes in Veterans' Use of Outpatient Care from 1992 to 2000," American Journal of Public Health, Vol. 95, No. 12, 2005, pp. 2246-2251; M. Cefalu, et al., "Enrollment in and Reliance on the VA Health Care System," in Current and Projected Characteristics and Unique Health Care Needs of the Patient Population Served by the Department of Veterans Affairs, Santa Monica, Calif.: RAND Corporation, RR-1165/1-VA, 2015, pp. 57-78 (as of August 11, 2016: http:/www.rand.org/pubs/research_reports/ RR1165z1.html).

${ }^{4}$ M. W. Link, Address Based Sampling: What Do We Know So Far? webinar, Alexandria, Va.: American Statistical Association, 2010.

${ }^{5}$ A. Rafferty, P. Walthery, and S. King-Hele, Analysing Change over Time: Repeated Cross Sectional and Longitudinal Survey Data, UK Data Service, University of Essex and University of Manchester, 2015.

${ }^{6}$ N. Buck, J. Ermisch, and S. P. Jenkins, Choosing a Longitudinal Survey Design: The Issues, Colchester: ESRC Research Centre on MicroSocial Change, University of Essex, 1996. 


\section{About This Report}

This report provides a detailed listing and analysis of surveys identified in the course of an assessment of ongoing survey research on post-9/11 U.S. military veterans. This information should be useful to researchers and policymakers interested in the breadth, quality, and representativeness of research on post-9/11 veterans that shows the trajectory of these individuals' reintegration into civilian life.

Funding for this study was provided by philanthropic contributions from RAND supporters and income from operations. RAND Labor and Population has built an international reputation for conducting objective, high-quality, empirical research to support and improve policies and organizations around the world. Its work focuses on children and families, demographic behavior, education and training, labor markets, social welfare policy, immigration, international development, financial decisionmaking, and issues related to aging and retirement with a common aim of understanding how policy and social and economic forces affect individual decisionmaking and human well-being.

For more information, contact

Krishna Kumar, Director

RAND Labor and Population

1776 Main Street, P.O. Box 2138

Santa Monica, CA 90407-2138

(310) 393-0411

or visit www.rand.org/labor.

\section{Acknowledgments}

The authors would like to thank our anonymous reviewers for their outstanding reviews and many helpful suggestions, and Rebecca Fowler for her editing of this report. We would also like to thank Joy Moini for her review of the draft document.

\section{Limited Print and Electronic Distribution Rights}

This document and trademark(s) contained herein are protected by law. This representation of RAND intellectual property is provided for noncommercial use only. Unauthorized posting of this publication online is prohibited. Permission is given to duplicate this document for personal use only, as long as it is unaltered and complete. Permission is required from RAND to reproduce, or reuse in another form, any of our research documents for commercial use. For information on reprint and linking permissions, please visit www.rand.org/pubs/permissions.

For more information on this publication, visit www.rand.org/t/RR1532.

(C) Copyright 2016 RAND Corporation

\section{www.rand.org}

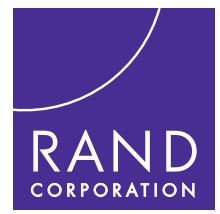

The RAND Corporation is a research organization that develops solutions to public policy challenges to help make communities throughout the world safer and more secure, healthier and more prosperous. RAND is nonprofit, nonpartisan, and committed to the public interest.

RAND's publications do not necessarily reflect the opinions of its research clients and sponsors. RAND ${ }^{\circledR}$ is a registered trademark. 